\title{
CULTURAL HERITAGE EXPOSED TO NATURAL HAZARDS: THE CASE STUDY OF THE CONVENT OF SAN DOMENICO IN MAIORI
}

\author{
R. LANDOLFO, C. TARANTINO*, F. PORTIOLI, L. CASCINI
}

\author{
${ }^{1}$ Department of Structures for Engineering and Architecture \\ University of Naples "Federico II", \\ via Forno Vecchio 36, 80134, Naples, Italy \\ e-mail: 1andolfo@unina.it, arch.cristarantino@gmail.com, fportiol@unina.it, lucrezia.cascini@unina.it
}

Keywords: Cultural Heritage, Masonry structures, Limit Analysis, Rigid block models, Lateral loads, Settlements.

\begin{abstract}
Nowadays it is widely recognized that structural interventions on cultural heritage buildings shall comply with the minimum intervention principle. The main goal is to enhance the structural capacity respecting, at the same time, the authenticity of the monument. As such, the correct interpretation of the current damage is a first fundamental step in the design of an efficient structural intervention. Within this framework, the paper presents the results of an in depth investigation carried out to assess the structural capacity of a complex monument affected by several deficiencies. The case study is the convent of Saint Domenico, a seventeenth century's masonry structure, belonging to the traditional architectural typology of the court building. The building is located in Maiori, a small town in the Amalfi Coast (Italy), included in the UNESCO World Heritage List since 1997 for its great cultural and naturalistic interest. The structure was abandoned during the 80s, and currently presents an extensive and diffuse crack pattern that is the consequence of several causes such as: the natural aging of material, the lack of maintenance, the modifications occurred during the centuries, the seismic events occurred in the past and the poor quality of the foundation soil. In this paper, starting from the knowledge acquisition path of the whole Convent, a special focus on the structural behavior of the East wing is provided. A numerical model of a cross section of the wing has been developed and analyzed considering the effects of lateral loads and settlements. The numerical analyses are carried out using LiaBlock_3D, an in-house software tool for the limit equilibrium analysis of rigid block assemblages. Results of the analyses are discussed in details and a comparison with the actual crack pattern of the structure is provided as well.
\end{abstract}

\section{INTRODUCTION}

The Convent of Saint Domenico (fig.1) is a seventeenth century's masonry building located in Maiori, a small town of the Amalfi Coast (Salerno, Italy), which is inscribed in the UNESCO World Heritage List since 1997, as it was recognized an "outstanding example of the Mediterranean landscape, with exceptional cultural and natural scenic values resulting from its dramatic topography and historical evolution"[1].

The importance of the building is related to its uniqueness features. Indeed, it contains interesting details of baroque architecture and remarkable artistic works, such as a fresco by the local painter Gaetano Capone. 
Very few buildings along the Coast can compete with its dimensions, whereby it represents an important spatial resource for the city and the entire coastal area. Furthermore, it is one of the few surviving elements of the historical urban fabric of Maiori.

From a structural assessment point of view, the analysis of the current performances of the building is very challenging. First of all, the actual structural configuration is really complex, because several manipulations were carried out over the centuries to adapt the original layout to new uses. Besides, the state of conservation of materials and structural components is very poor: the building shows a severe deterioration, as it was abandoned since the ' 80 , when a strong earthquake produced severe damages, and it has never been restored. Finally, the Convent is also threatened by several natural hazards, being exposed to high landslides risk, to floods, and to earthquakes, which already hit the building in the recent past.

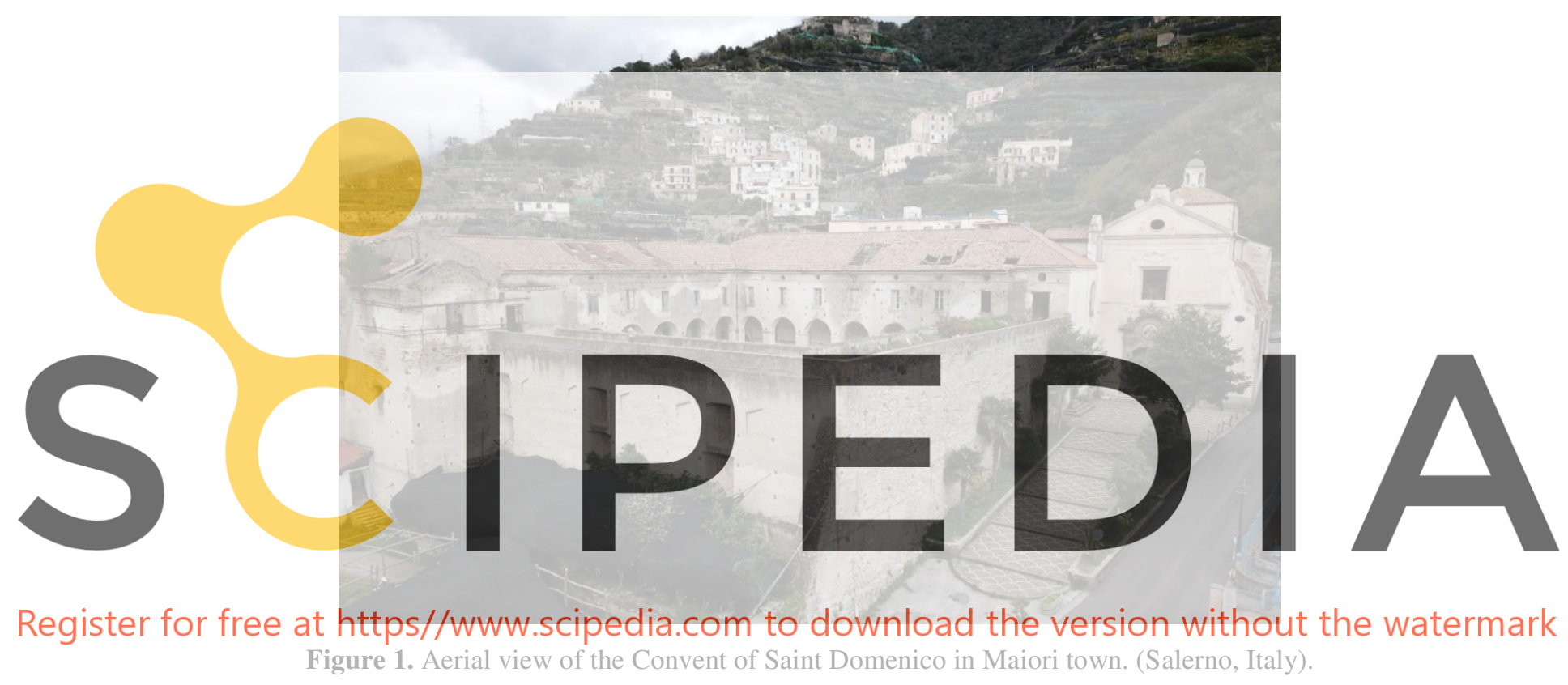

As a matter of fact, a proper interpretation of the actual performances of the Convent of Saint Domenico requires an interdisciplinary and multidisciplinary approach, where experts coming from different fields of expertise, provide their contributions to proper characterize the hazards that threaten the building and quantify its vulnerability. Indeed, this case study is under investigation within the framework of the research project PERICLES- funded by the Italian Ministry of Education, Universities and Research in 2017- and aimed to develop sustainable strategies for the protection of the Cultural Heritage threatened by natural hazards ${ }^{[2]}$.

Within the framework of the present study, a detailed analysis of a portion of the Convent is presented and a set of numerical analyses are carried out to evaluate the structural capacity of the selected part against lateral loads and settlement. The structural analyses were carried out using LiABlock_3D, an in-house software tool for the limit equilibrium analysis of masonry structures modelled as an assemblage of three-dimensional blocky structures, which provides as output the most vulnerable collapse mechanism for a given loading condition ${ }^{[3][4]}$. The software is based on a 'point-contact' formulation and implements the lower bound problem of limit analysis. The numerical model is an assemblage of rigid bodies interacting one another 
through no tension-friction contacts characterized by infinite compressive strength. Static variables are the unknown shear forces and the normal force acting at each contact point. The external forces are the known dead loads and the live loads acting at the centroid of each block, the last ones being expressed as a function of the other unknown of the static limit analysis problem, that is the collapse load multiplier. The failure mechanism associated to the solution of the lower bound problem is derived from the kinematic variables which can be obtained from the dual limit analysis problem, corresponding to the upper bound - or displacement based formulation. Further details of the formulation can be found in ${ }^{[3][4]}$.

It should be noted that similar modelling approaches based on thrust line analysis or variational formulation for limit analysis of failure mechanisms induced by settlements have been also developed in the literature ${ }^{[5]}$. Incremental solution procedures based on rigid blocks interacting at unilateral contact interfaces for the analysis of the response in the large displacement regime were presented in ${ }^{[6][7]}$. Applications of alternative numerical formulations can be also found in the literature such as the distinct element method ${ }^{[8]}$, homogenized, discontinuous or block-based finite element models ${ }^{[9][10][11][12]}$ and rigid-body spring models ${ }^{[13]}$. The non-smooth contact dynamic method was also applied for the analysis of masonry panels subjected to settlements ${ }^{[14]}$.

The paper is structured as followings: section 2 introduces the case study, providing the most relevant historical information useful for the structural characterization of the building. In Section 3 a damage analysis is introduced and details of the surveyed crack patter are reported. The numerical model developed for this stud with the analysis carried a comparison with the

2 THE CONVENT O
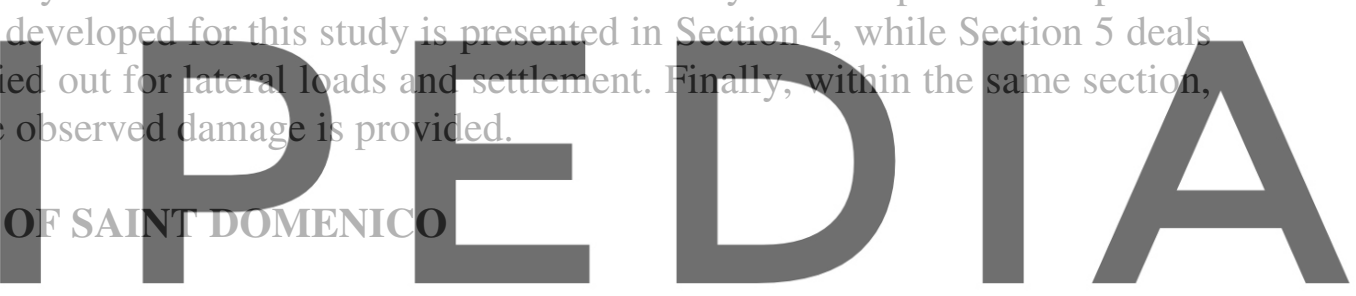

2.1 Brief history of the building

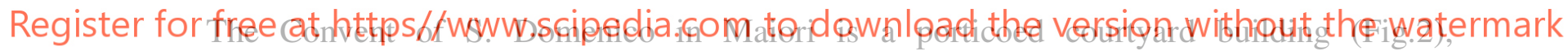

characterized by a complex plan configuration, which is the consequence of several manipulations and adaptation carried out during the centuries, to solve unexpected problems and adapt the construction to new functions ${ }^{[15]}$. The construction process, which started in 1650th, was long and complicated, due to several structural instabilities caused by the poor quality of foundation soils. In the 1809, after the suppression of the religious Orders, the Convent was abandoned and left without any use for about 50 years. In 1865, the local Authorities acquired the whole building and settled inside three different functions: the northside of the ground floor of the Convent became a courthouse, the south-west a jail and the whole first floor became a school. Consequently, very invasive restoration works were carried out to adapt the old construction to the new functions: lofts were created at the ground floors and new windows were opened in the bearing walls. At the first floor, large arched openings were created in the transverse walls to define the classrooms, enlarging the old monks' cells. In 1980, a strong earthquake heavy damaged the structures and subsequently the building was definitively closed and abandoned. In 1985, a new project of restoration was launched but only partially completed, due to the lack of funds. Nowadays, the building is still closed, abandoned and in critical condition and used by the administration as a warehouse. 


\subsection{Description of the building}

The Convent of San Domenico is composed by four bodies of different width and height, placed around a square courtyard of 32 side length meters. Two of them (the east and the north blocks) develop for two levels, while the last two (the South and the West blocks) feature a single above-ground level and only consist of a portico covered by a panoramic terrace facing the sea (fig 2).
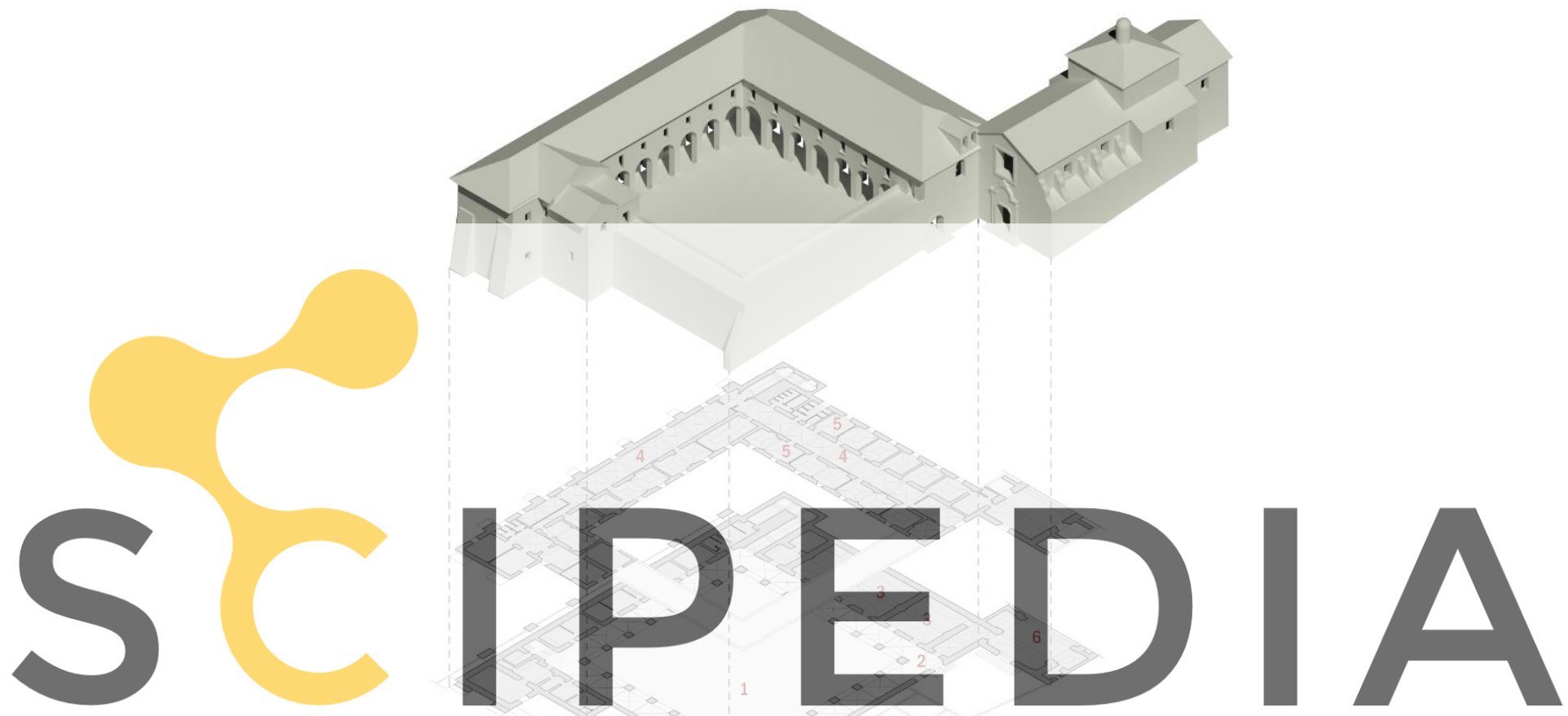

Register for free at https//www.scipedia.com to download the version without the watermark

Figure 2.: The architectural asset of the Convent of Saint Domenico: 1) the courtyard; 2) the portico; 3) the big ground floor halls; 4) the first floor corridor; 5) the monks' cells; 6) the Church.

The Church is located on the south east corner, connected to the cloister along the edge, and sharing with it a bearing wall. At the ground floor, along the north and the east sides big barrel vaulted halls open off, while the south and west porticos have blind back walls. On the first floor a long corridor runs the whole building and serves all the rooms once being the monks' cells. The vertical connection was once granted by two stairways. The one on the east side is a three ramps stairway, covered with flying barrel vaults. That on the west side was cut after the first ramp by the nineteenth century's transformations, thus it is no longer serviceable.

The thickness of the masonry walls ranges between 1,2 meters (at the ground floor) and 0,6 meters (on the last level). The horizontal structures consist of a great variety of vaulted structures made of yellow tuff: big barrel vaults cover the rooms at the ground floor, while cloister vaults roof the sequence of monastery cells; groin vaults span along the portico and the corridor at the first floor. The roof is made by double slopes timber structures, covered by clay 
romanstyle tiles. The foundation structures are disomogeneous and placed on different laying surfaces: superficial continuous masonry foundations, in calcareous stone; deep masonry foundations of pillars connected by arches, in calcareous stone; deep masonry foundations of pillars connected by walls, in calcareous stone.

The east wing, which is the focus of the present paper, is characterized by a modular scheme of large square rooms at the ground floor, $8.00 \mathrm{~m}$ large and 9.00 width, covered by barrel vaults, 7.00 meters high at the ceilings. Smaller rooms are located on the first floor, with an average area of $16 \mathrm{~m}^{2}$ each, and covered by square cloister vaults, $4.00 \mathrm{~m}$ large. The masonry walls at ground floor are made of roughly cut stones of variable dimensions and presents and average thickness of $1.00 \mathrm{~m}$. At the first floor, masonry walls are made of grey tuff blocks with an average thickness of $0.80 \mathrm{~m}$. Special conditions can be observed in the building elevation, where it is possible to find a relevant number of masonry walls that lean against the top of the barrel vault of the lower floor.

Details of the damage status of the whole building and of the selected wing are provided hereafter.

\section{THE DAMAGE SURVEY}

The building currently exhibits an extensive and diffuse crack pattern that, generally speaking, presents recurrent elements and increases in intensity and thickness from the ground upwards (Fig. 3).
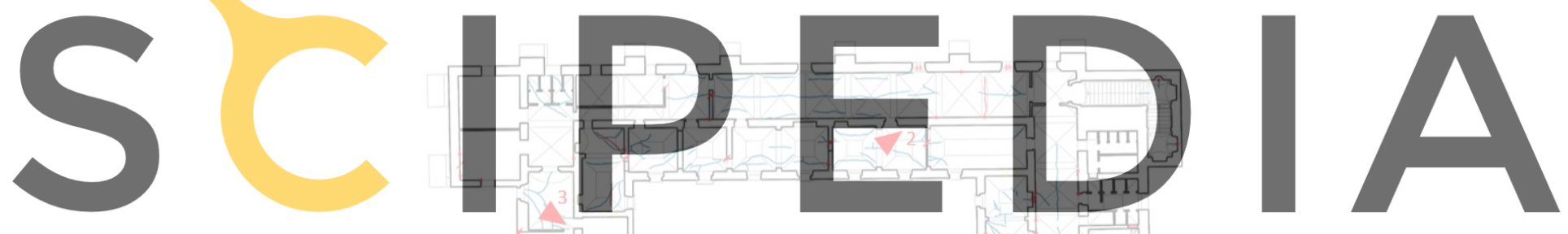

Register for free at https//www.scipedia.com to download the version without the watermark

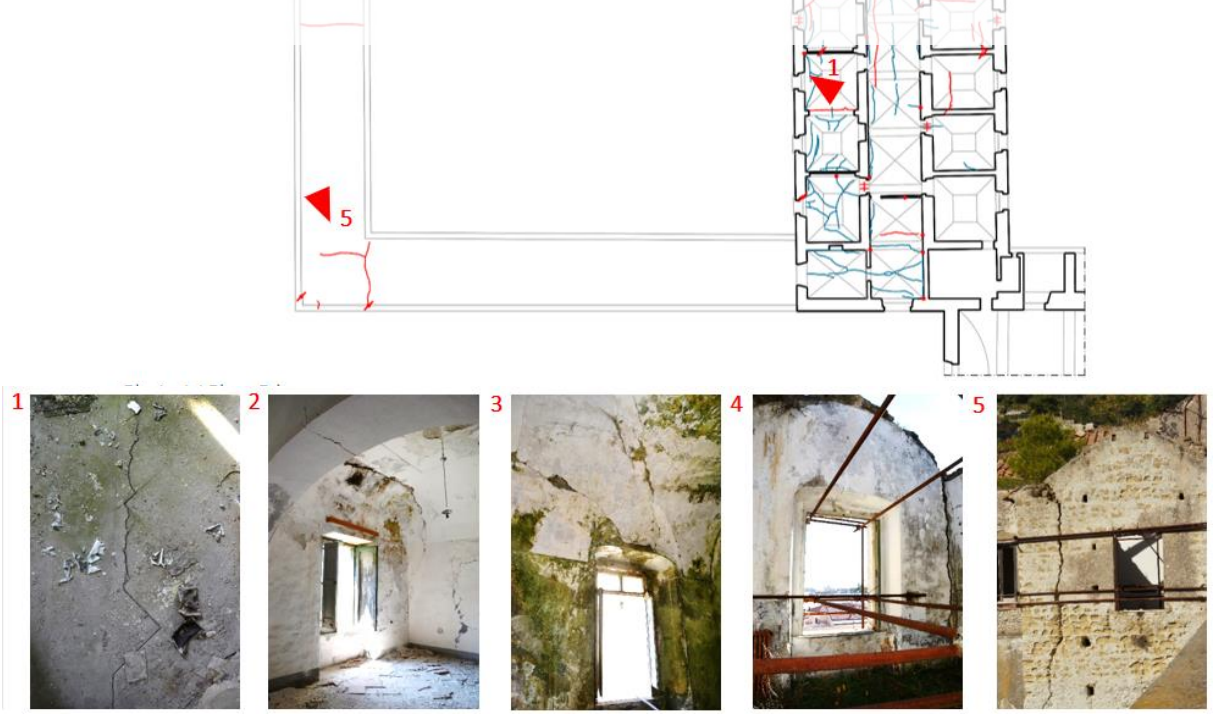

Figure 3. Damage pattern at the first floor 
The groin vaults of the portico and of the corridor at the first floor show cracks in the centerline and at the attachment to the walls, corresponding to the typical three-hinged mechanism; the trough vaults of the monks' cells exhibit diagonal cracks and multiple dense cracks parallel to the courtside wall.

As for the East wing (Fig. 4), a different crack pattern is observed, which differs from the one observed in the rest of the building. Indeed, the big barrel vaults of the ground floor halls are completely detached from the head wall separating them from the court. At the first floor, the trough vaults of the monks' cells on the courtside show a more complex and braided crack pattern. Parabolic fissures develop on the shear/transverse walls and some cracks open out on the floors.

A partial collapse of the roof can be observed at the middle length of the block, not referable to a break of the timber structure, which still appears in good conditions. Moreover, the presence of sub vertical cracks on the foundation arches in the south-east corner is reported by the geognostic study associated to the 1987 restoration project.

The interpretation of the crack pattern in this area of the building is not straightforward, as it seems to be the result of different phenomena that acted on the building. As such, a numerical model of a recurrent section type of the east wing was developed and analyzed for different loading conditions, as discussed in the following sections.
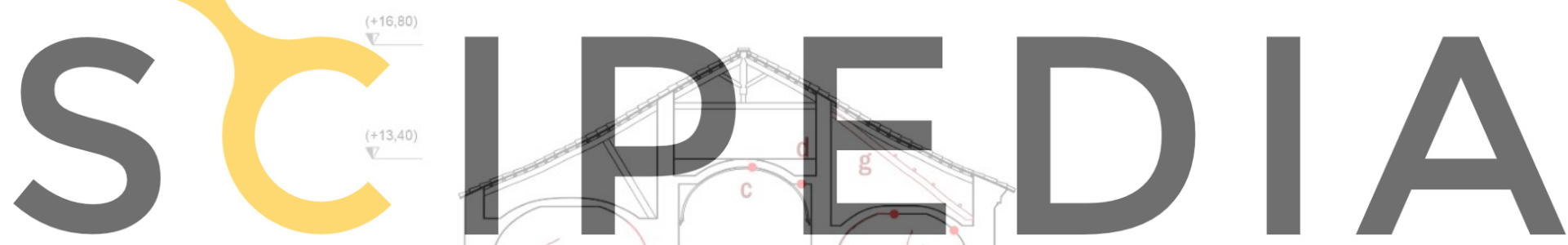

Register for free at https//www.scipedia.com to download the version without the watermark

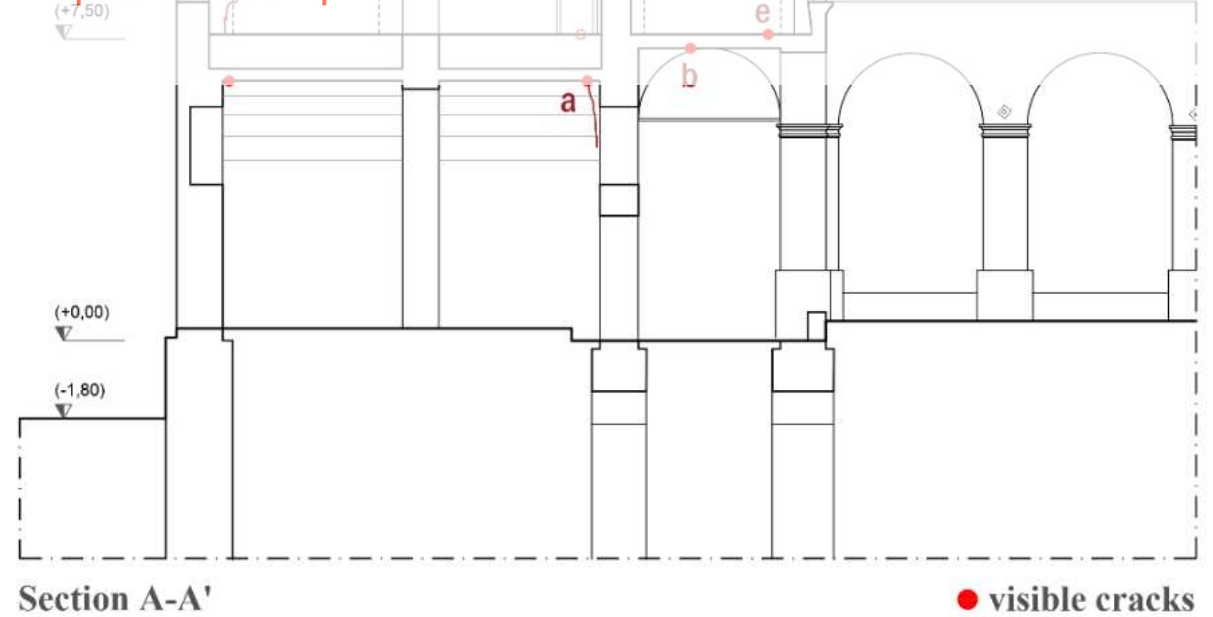

Figure 4.: Crack pattern in the East wing 


\section{NUMERICAL MODEL OF THE EAST WING}

The numerical model of the east wing (Fig. 5) was developed for a characteristic transverse section, which is representative of the whole wing, considering the modularity of this part of the Convent. The section is obtained in correspondence of the symmetry plane between two consecutive spans of the portico and includes the most relevant structural elements of the wing. These are: at the ground floor, the arch separating the crossing vaults of the portico, and the barrel vault of the big hall on the back, in its centerline; at the first floor, the transverse walls between the monks' cells, with their low arch inner openings, and the arch between the crossing vaults of the central corridor. Also the timber roof was included in the model.

To solve some modelling issues deriving from the gap between the two dimensional model and the three dimensional conception of the construction, special components were created.

It is the case of the sub arch of the ground floor barrel vault, which develops in the orthogonal direction of the plane considered in the analysis. A support block has been introduced in its place to sustain the left wall of the first floor corridor. A similar condition is that of the barrel vault, which appears in its axial section. In order to consider the low grade of interlocking of this structure to the head walls and their possible detachment in a collapse mechanism, as it can be usually observed in historical constructions, the blocks representing the vault thickness are provided with a very short support.
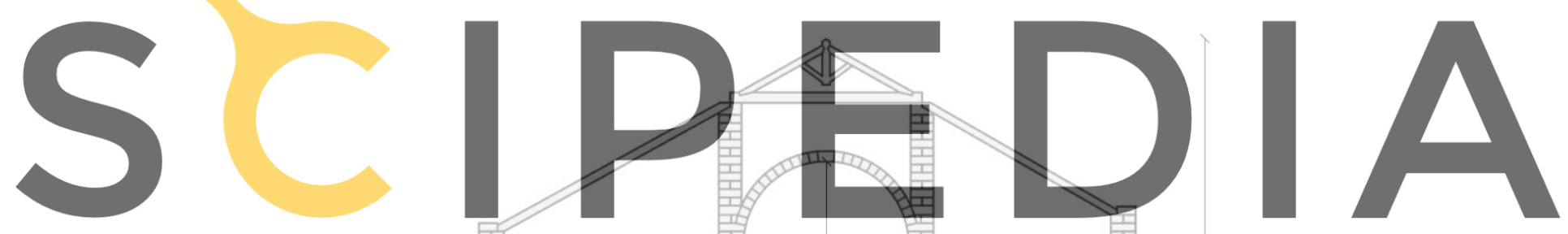

Register for free at https//WWW.scipedia.com to downtoad the version without the watermark

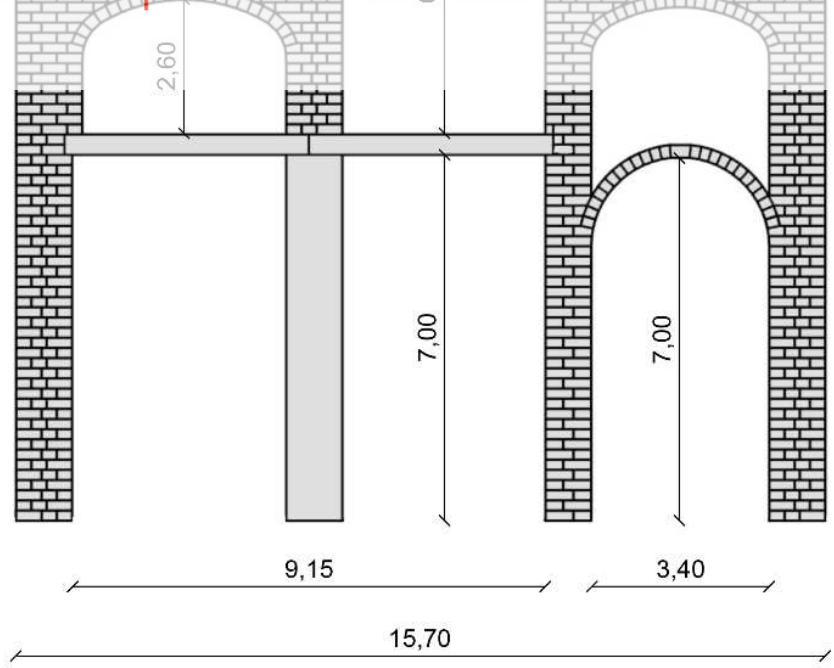

Figure 5.: The numerical model of the east wing (dimensions in meters) 
The numerical model is composed by an assemblage of 685 rigid blocks. discretization of the structure in rigid blocks does not reproduce exactly the real masonry texture but was defined so as reproduce the average size of the real stones. A refined discretization was adopted along the imposts of the arches to enable the freest formation, along the whole structure, of the hinges required by the collapse mechanisms associated to the imposed actions.

The masonry walls and pillars are built with parallelepiped shape blocks. The block maximum dimensions are 50x20x40 cm. Blocks with different shape have been employed in the arches thickness and at the arches springing, to better reproduce the shape of the voussoirs and the interlocking at the attachment sections.

Additional rigid blocks have been used to model the timber structure of the roof. Apart from the geometry of the structural configuration, the additional data required as input by LiaBlock_3D for the analysis are related to the material properties. The weight per unit volume $\rho$ of the masonry was assumed equal to $21 \mathrm{kN} / \mathrm{m}^{3}$ and the value of the friction coefficient $\mu$ was set equal to 0.6

\section{NUMERICAL ANALYSES}

\subsection{Lateral load analysis}

The numerical analyses for lateral loads have been carried out by applying a set of lateral forces, applied to the centroid of each rigid block, acting along the x-direction in two opposite directions.
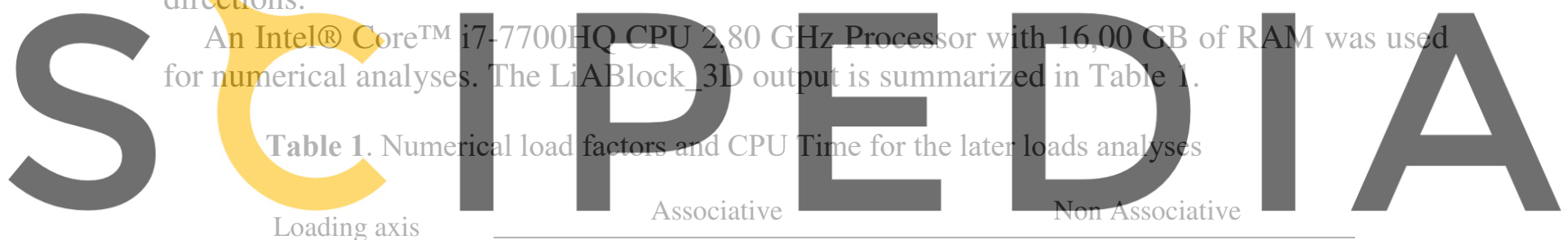

Load factor o Associative

Load factor

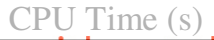

Register for free+at https//wWw.scipedia.com tø. ohownload theoversion withosut the watermark 0.084 0.5679 0.084 3.8537

Figures $6 \mathrm{a}$ and $6 \mathrm{~b}$ show the collapse mechanisms corresponding to the non-associative solution of the two in-plane seismic analyses, in the positive and negative $\mathrm{x}$ directions respectively. When the load acts in the x positive direction, the collapse condition occurs for a low value of the load factor. The overturning of the courtyard facade is activated and, as a consequence, a typical three hinges mechanism develops in both the round and low arches of the right span of the section. The mechanism also causes the sliding of the timber beam and, thus, the roof collapse. When the load acts in the $\mathrm{x}$ negative direction, the load factor needed for the collapse is higher. The left and the middle spans of the section almost behave as a unique block, overturning and causing the serious damage visible in the right span of the section. Here the collapse occurs again with the three hinges mechanism of the arches and the sliding of the roof's beam.

The global damage of the seismic in-plane analysis is partly compatible with the surveyed crack pattern, as it was expected, since no restoration works have been done after the 80's earthquakes. Nevertheless, it contemplates a slight damage of the innermost structures of the section and doesn't detect the floor cracks at the first level. 


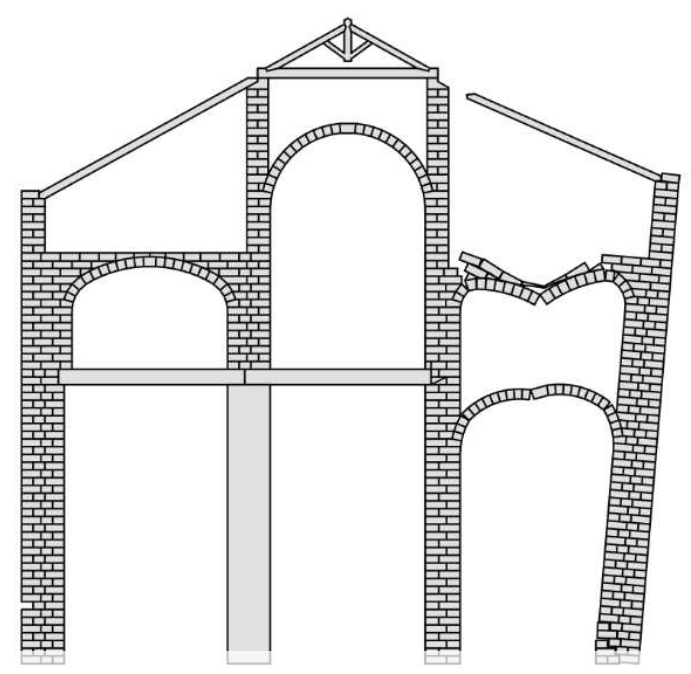

a)

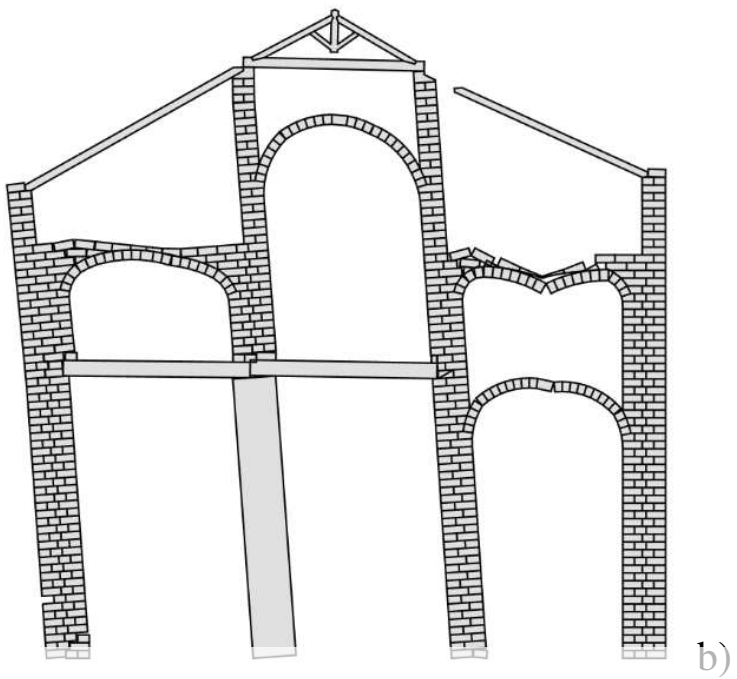

Figure 6: Plots of the collapse mechanisms provided by LiaBlock_3D for the non associative solutions. Lateral loads acting along the: a) $\mathrm{x}$ positive axis; b) $\mathrm{x}$-negative axis

\subsection{Settlement analysis}

The analysis for imposed settlement has been carried out considering that, as highlighted in the previous paragraphs th

a significant hazard inc resulting in differentia

Indeed, available stu

by different granular de
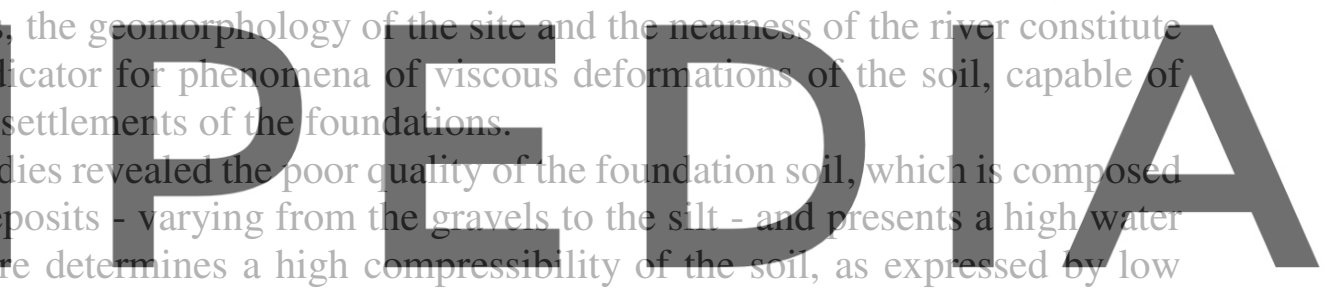

value of the weight per unit and by the oedometric modulus.

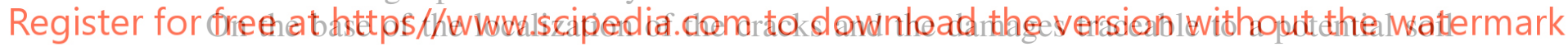

failure, two different schemes of ground vertical displacement were implemented. The first one considers a uniform vertical displacement imposed at the base of the portico's pillar (Fig7a); the second, examines the case of the same movement imposed at the base of the portico's back wall (Fig7b).

The LiABlock_3D output is summarized in Table 2. For each imposed settlement, the table reports the base reaction at collapse, calculated for the associative and non-associative solution, and the CPU Time. In such a case, considering that the collapse mechanisms do not imply significant sliding, the difference between the associative and non-associative solutions are negligible.

Table 2: Base reaction values at collapse and CPU Time for the settlement analysis

\begin{tabular}{lcccc}
\multirow{2}{*}{ displacement axis } & \multicolumn{2}{c}{ Associative } & \multicolumn{2}{c}{ Non Associative } \\
\cline { 3 - 5 } & Base reaction & CPU Time $(\mathrm{s})$ & Base reaction & CPU Time (s) \\
\cline { 1 - 3 } \cline { 3 - 5 }$-\mathrm{z}(\mathrm{A})$ & $124.358 \mathrm{kN}$ & 0.4582 & 123.7757 & 1.2774 \\
$-\mathrm{z}(\mathrm{B})$ & $121.481 \mathrm{kN}$ & 0.5053 & 121.296 & 1.3056
\end{tabular}



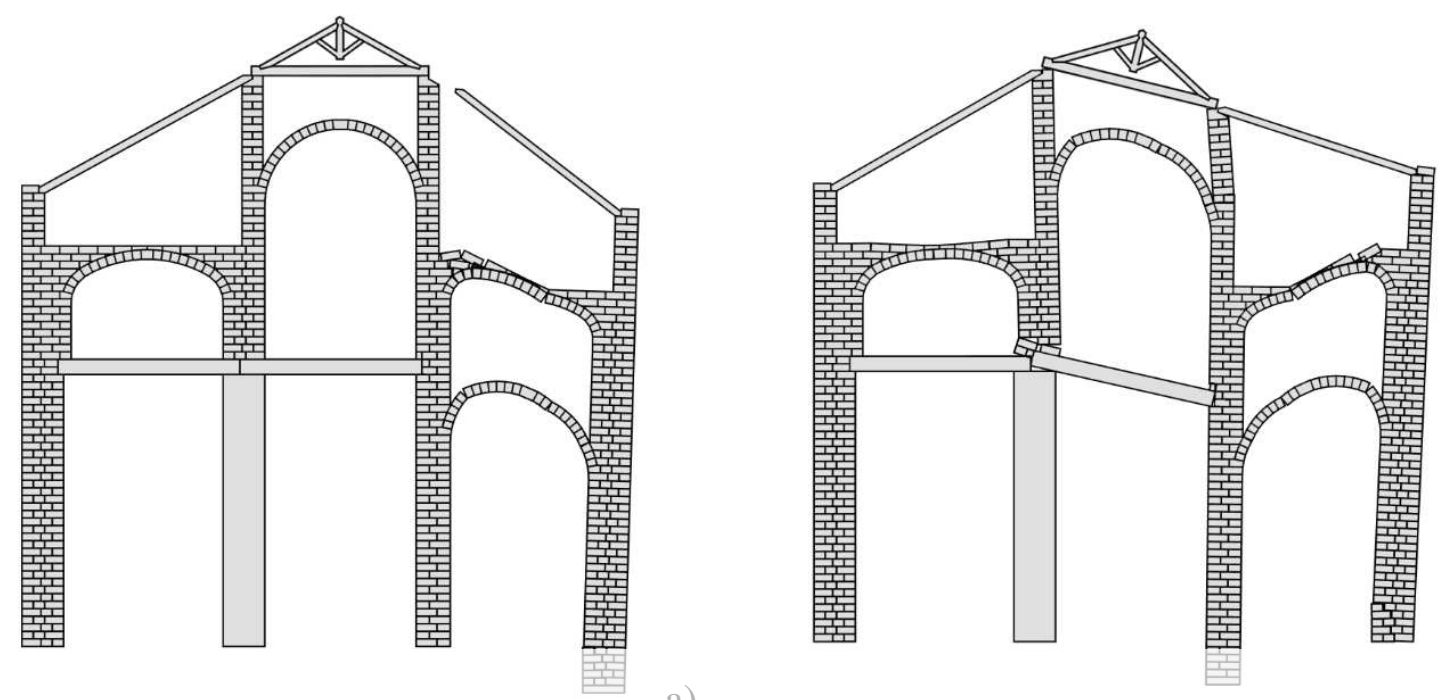

a)

Figure 7: Non associative solutions for the downward displacement of the portico's pillar (a), and the portico's back wall(b).

For the first settlement's scheme, the failure involves only the first span of the section, corresponding to the portico side. The collapse occurs with a three hinges mechanism in the ground floor arch and a two hinges mechanism in the low arches at the first floor. The different

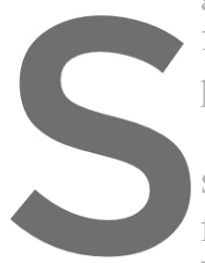
failure mode is related to the different geometry or pillar and the sliding of

For the second settlement's scheme, the still occurs with a three floor corridor, while a ty
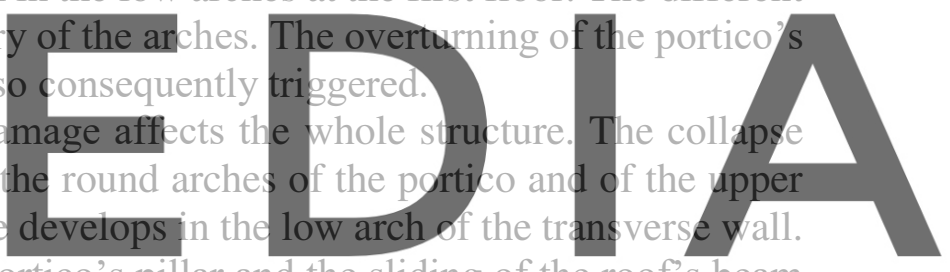

This, again, results in the overturning of the portico's pillar and the sliding of the roof's beam

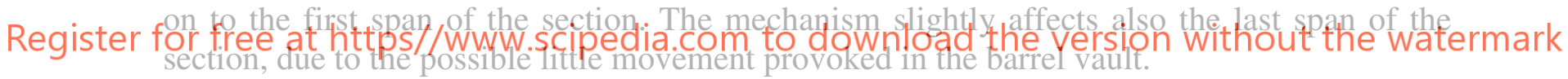

Between the two collapse mechanism predicted by the numerical model, the second one, corresponding to the B settlement scheme, is in good agreement with the surveyed crack pattern.

The mechanism catches almost all the existing cracks reported in the section of fig 4: at the ground floor, the barrel vault detachment from the head wall on the portico side (lesion a) and the cracks in the covering structures of the portico (lesion b); at the first floor, the cracks in the vaults and arches of the corridor (lesion c and d), at the floor (lesion e) and in the transverse wall (lesion $\mathrm{f}$ ) of the right room, and the failure of the roof (lesion g).

Also the parabolic fissures in the upper left room (lesion $h$ ) can be traced to this failure mode.

It should be noted that the correspondence of the numerical result to the crack pattern is valid with reference to the analyzed section. Out from this plane of symmetry, the cracks follow a path determined by the complex three dimensional development of the vaulted structures and the characteristic and variable constructive texture. 


\section{CONCLUSIONS}

In this paper, the damage analysis of the east wing of the Convent of Saint Domenico has been presented. A rigid block limit analysis has been carried out with the software LiABlock_3D to investigate the structural response of the numerical model against two different loading conditions, which are lateral loads and settlements. The main goal was to analyze the current crack pattern and to better understand the origin of the damages produced by the two phenomena. The results of the analysis confirmed that the current crack pattern can be ascribed to the concurrent action of the lateral loads and settlement. As such, further development of the study will address more in details the interaction between the structure and the soil and will also extend the analysis to a full 3D model, to better analyze the behavior of the vaults in the spatial model.

Acknowledgements. The financial support of PRIN 2015 Program by the Italian Ministry of Education, University and Research (MIUR) is gratefully acknowledged for funding the research project "Protecting the Cultural Heritage from water-soil interaction related threats" (Prot. No. 2015EAM9S5), which is the main framework of the study presented in this article.

\section{REFERENCES}

[1] UNESCO, «Decision report: Inscription: The Costiera Amalfitana (Italy). CONF 208 VIII.C.», 1997.

[2] R. Landolfo et al., «PERICLES Case studies: the Convent of S. Domenico in Maiori», 2020.

[3] F. P. A. Portioli, «Rigid block modelling of historic masonry structures using mathematical programming: a unified formulation for non-linear time history, static pushover and limit equilibrium analysis», Bulletin of Earthquake Engineering, vol. 18, n. 1, pagg. 211-239, 2020, doi: 10.1007/s10518-019-00722-0.

[4] L. Cascini, R. Gagliardo, e F. Portioli, «LiABlock_3D: A Software Tool for Collapse Mechanism Analysis of Historic Masonry Structures», International Journal of Architectural Heritage, 2018, doi: 10.1080/15583058.2018.1509155.

[5] P. Zampieri, M. Amoroso, e C. Pellegrino, «The masonry buttressed arch on spreading support», Structures, vol. 20, pagg. 226-236, 2019, doi: https://doi.org/10.1016/j.istruc.2019.03.008.

[6] A. Tralli, A. Chiozzi, N. Grillanda, e G. Milani, «Masonry structures in the presence of foundation settlements and unilateral contact problems», International Journal of Solids and Structures, vol. 191-192, pagg. 187-201, 2020, doi: https://doi.org/10.1016/j.ijsolstr.2019.12.005.

[7] F. Portioli e C. Lucrezia, «Assessment of masonry structures subjected to foundation settlements using rigid block limit analysis», Engineering Structures, vol. 113, pagg. 347-361, 2016, doi: 10.1016/j.engstruct.2016.02.002.

[8] T. T. Bui, A. Limam, V. Sarhosis, e M. Hjiaj, «Discrete element modelling of the inplane and out-of-plane behaviour of dry-joint masonry wall constructions», Engineering Structures, vol. 136, pagg. 277-294, 2017, doi: https://doi.org/10.1016/j.engstruct.2017.01.020. 
[9] R. Landolfo et al., «Rigid block and finite element analysis of settlement-induced failure mechanisms in historic masonry wall panels», Frattura ed Integrità Strutturale, vol. 14, pagg. 517-533, 2020, doi: 10.3221/IGF-ESIS.51.39.

[10] G. De Felice e M. Malena, «Failure pattern prediction in masonry», Journal of Mechanics of Materials and Structures, vol. 14, n. 5, pagg. 663-682, dic. 2019, doi: 10.2140/jomms.2019.14.663.

[11] A. M. D’Altri, S. D. Miranda, G. Castellazzi, V. Sarhosis, J. Hudson, e D. Theodossopoulos, «Historic Barrel Vaults Undergoing Differential Settlements», International Journal of Architectural Heritage, vol. 0, n. 0, pagg. 1-14, 2019, doi: 10.1080/15583058.2019.1596332.

[12] C. Alessandri, M. Garutti, V. Mallardo, e G. Milani, «Crack Patterns Induced by Foundation Settlements: Integrated Analysis on a Renaissance Masonry Palace in Italy», International Journal of Architectural Heritage, vol. 9, n. 2, pagg. 111-129, 2015, doi: 10.1080/15583058.2014.951795.

[13] S. Galassi, G. Misseri, L. Rovero, e G. Tempesta, «Failure modes prediction of masonry voussoir arches on moving supports», Engineering Structures, vol. 173, pagg. 706-717, 2018, doi: https://doi.org/10.1016/j.engstruct.2018.07.015.

[14] V. Acary e M. Jean, «Numerical modeling of three dimensional divided structures by the Non Smooth Contact dynamics method: Application to masonry structures», presentato al The Fifth international Conference on Computational Structures Technology 2000, set. 2000, pagg. 211-221, Consultato: apr. 30, 2020. [In linea]. Available at: https://hal.inria.fr/inria-00425357.

[15] C. Tarantino, «Beni culturali espsoti ai pericoli naturali. Il caso studio dell'ex Convento di San Domenico a Maiori», University of Naples Federico II, 2018. 